University of Wollongong

Research Online

Faculty of Business - Papers (Archive)

Faculty of Business and Law

$1-1-2018$

Bank Work Experience Versus Political Connections: Which Matters for Bank Loan Financing?

Xiaofei Pan

University of Wollongong, xpan@uow.edu.au

Gary G. Tian

Macquarie University, gtian@uow.edu.au

Follow this and additional works at: https://ro.uow.edu.au/buspapers

Part of the Business Commons

Research Online is the open access institutional repository for the University of Wollongong. For further information contact the UOW Library: research-pubs@uow.edu.au 


\title{
Bank Work Experience Versus Political Connections: Which Matters for Bank Loan Financing?
}

\author{
Abstract \\ This paper examines how bank lending decisions are affected either by executives' connections with \\ banks, through their former banking experience, or by their political connections with governments, using \\ a sample of bank loans granted to Chinese listed non-state-owned enterprises (SOEs) from 2003 to 2010. \\ We find that bank loans are more closely related to profitability for firms with bank connections, while \\ firms' political connections weaken this relationship. We further find that the influence of bank \\ connections is more significant for firms from less supported industries or less developed regions. \\ Furthermore, firms with bank connections are less likely to become financially distressed after the \\ initiation of their bank loans and experience higher future stock returns, while firms with political \\ connections experience the opposite outcome. Overall, our results indicate that in the context of a \\ relationship-based economy like China, firms' connections with banks create value by alleviating \\ information asymmetry and improving banks' lending decisions, while political connections result in \\ capital misallocation and subsequent deterioration in performance.

\section{Disciplines \\ Business}

\section{Publication Details} \\ Pan, X. \& Tian, G. (2018). Bank Work Experience Versus Political Connections: Which Matters for Bank \\ Loan Financing?. International Review of Finance, Online First 1-32.
}




\title{
Bank work experience versus political connections: Which matters for bank loan financing?
}

\begin{abstract}
This paper examines how bank lending decisions are affected either by executives' connections with banks, through their former banking experience, or by their political connections with governments, using a sample of bank loans granted to Chinese listed nonSOEs from 2003 to 2010. We find that bank loans are more closely related to profitability for firms with bank connections, while firms' political connections weaken this relationship. We further find that the influence of bank connections is more significant for firms from less supported industries or less developed regions. Furthermore, firms with bank connections are less likely to become financially distressed after the initiation of their bank loans and experience higher future stock returns, while firms with political connections experience the opposite outcome. Overall, our results indicate that in the context of a relationship-based economy like China, firms' connections with banks create value by alleviating information asymmetry and improving banks' lending decisions, while political connections result in capital misallocation and subsequent deterioration in performance.
\end{abstract}

Keywords: Bank work experience, Political connections, Bank lending decisions, Chinese listed firms

JEL: E51, G32, G34 


\section{Introduction}

Recent literature has documented that the bank-firm relationship is valuable for firms' bank loan financing. One strand of literature emphasizes the importance of social connections between bank executives and borrowers, since this social connection enables banks to catalyse the borrowers' proprietary and specific information and reduce banks' monitoring costs (Engelberg et al., 2012; Haselmann et al., 2013). Another strand of literature, with respect to relationship banking/lending, suggests that banks may invest in costly information production by building a close relationship over time with borrowers (Boot and Thakor, 1994). Relationship lending allows banks to learn about borrowers more easily at a lower cost. However, there is mixed evidence regarding whether relationship lending is beneficial for borrowers. Some studies argue that relationship lending can reduce banks' monitoring costs and benefit borrowers with lower financing costs (Boot, 2000; Behr et al., 2011; Bharath et al., 2011), while other studies propose the alternative view that relationship lending can lead to firms being locked in, and that banks may seek more rents due to monopoly power through increasing financing costs (Sharpe, 1990; Rajan, 1992; Kano et al., 2011).

In a departure from previous studies, but complementary to them, our focus is to explore another channel through which the bank-firm relationship is built, namely the bank work experience of firms' executives. Through this work experience, executives have built up their personal relationship with bank managers in that bank and may even extend their relationships to those in other banks. Recent evidence has suggested that firms' connections with banks, accumulated through firm executives' banking experience, are valuable for firms in terms of applying sophisticated financial policies (Custodio and Metzger, 2014) and better acquisition decisions (Huang et al., 2014). However, these studies almost exclusively focus on developed markets and little is known about the financial implications of the bank-firm relationship in China, whose economy is known to be relationship-based.

Meanwhile, it has also been widely documented that political connections based on executives' close connections with governments bring various benefits to firms in accessing financial resources, such as bank loans and equity issuing, through rent seeking from government regulations or government lobbying (Cull and Xu, 205; Claessens et al., 2008; Faccio, 2010; Li et al., 2008; Houston et al., 2014).

Overall, there is a clear connection between the influence of political connections and the bank-firm relationship (we use the term "bank connections" hereafter) on bank lending. Thus, we are interested in investigating the relative impacts of bank connections and political 
connections on conferring access to bank loans and explaining how banks make lending decisions. In particular, this paper intends to answer the question "whether and how do bank and political connections affect banks' lending decisions?" The answer to this question is an essential element in gauging firm value and financial implications in a relationship-based economy, and may present a complementary perspective to existing literature. Following existing studies, we use the sensitivity of the amount of bank loans to firm profitability as the proxy for bank lending decision. This is because banks have strong incentives to allocate more capital to financially healthy firms, thus reflected by a strong sensitivity of bank loan size to firm profitability (Zheng and Zhu, 2013).

This paper conducts the research using non-state-owned enterprises (non-SOEs) in China, because the non-SOE sector in China has provided an ideal institutional environment in which to address these issues for several reasons, as explained below.

First, China's financial system and banking industry are largely controlled by the state, and bank loans are more likely to flow to SOEs than non-SOEs. As a result, non-SOEs face many obstacles in trying to access external finance in order to survive (Firth et al., 2009). Using China's non-SOEs as the sample can avoid the diluted effect of state ownership in SOEs, and allow us to identify the causal effects of both kinds of connection on firms' financial policies and banks' lending decisions.

Moreover, there are cross-sectional variations in government supporting policies across industries, as every five years the government announces a "Five Year Plan" specifying that particular industries will be supported by government policies. There are also cross-sectional variations in institutional environments across provinces in China (Fan et al., 2011). Thus the Chinese setting provides a good environment and creates cross-sectional variations which may shape the effects of bank connections and political connections on banking finance and banks' lending decisions. Such a cross-regional approach within one country makes it possible to control for the role of accounting rules, culture and other country-level variables (Li et al., 2009). Therefore, an in-depth case study of a particular country's experience can provide a useful complement to cross-country regressions. For all these reasons, our sample facilitates this research into exploring the financial implications of bank connections and political connections with respect to firms' banking finance and banks' lending decisions.

We conduct analyses at the bank loan level because there are problems of identification with firm-level data, since the results could be due to unobserved heterogeneities in firms which are correlated with bank lending decisions and connections. Our results show that firms with either bank connections or political connections have access to more bank loans. 
We also find that bank connections can enhance banks' lending decisions by strengthening the positive relationship between bank loan size and firm profitability, while political connections weaken this relationship. Our empirical results further show that the effect of bank connections is more significant for firms from less supported industries or less developed regions. By focusing on subsequent performance, we find that firms with bank connections perform better over three-year periods after the initiation of their bank loans, while those with political connections perform worse. Additionally, we find that both firm and bank shareholders highly value bank loans to firms with bank connections, as reflected by higher abnormal returns around bank loan announcements, and discount the value of bank loans to firms with political connections. Our main findings are robust to corrections for alternative measurements of connections and an alternative sample. Even though the endogeneity issue is less likely to be ruled out completely, we have conducted further tests to mitigate the endogeneity issue and confirm the robustness of our main results, including using the Heckman two stage and propensity score matching methods. These findings suggest that bank connections reinforce the use of profitability in allocating capital and create value for firms, while political connections are more likely to result in capital misallocation, which may reduce firm value.

Our study is related to several strands of a growing body of literature. First, we contribute to literature on the implications of managerial networks for corporate financial decisions. Previous studies have examined the effects of bank connections and political connections on firms' bank financing separately, and there is no evidence to compare the relative impact of bank connections and political connections. This study fills this gap. In particular, while we have confirmed the existing findings that political connections lead to more bank loans, our findings indicate that political connections distort capital allocation and cause subsequent underperformance after bank loans have been granted. We argue that connections with banks, a more direct and specific measurement for bank-firm relationships than executives' political connections, more effectively influence Chinese non-SOEs' success in obtaining bank loans, and further improve banks' lending decisions.

Secondly, our study adds to the evolving literature on agency problems and information asymmetry. We provide evidence from an emerging market that connections between firms and banks encourage the transfer of information between them, which results in optimal lending contracts, due to either better information flow or more efficient monitoring. Furthermore, our study also advances the view that the financial work experience of executives/directors matters for firm value and policies (Custodio and Metzger, 2014; Huang 
et al., 2014), and we provide strong evidence that banking experience matters for firms' financial policies and the enhancement of firm value.

The rest of the paper proceeds as follows: Section 2 discusses the institutional background and develops the hypotheses; Section 3 describes the data and methodology; Sections 4 and 5 discuss the empirical results; and Section 6 concludes.

\section{Institutional background and development of hypotheses}

In this section we describe the institutional background in China related to our study, and develop corresponding hypotheses based on existing theories and China's institutional system.

\subsection{Banking industry and banks' lending decisions}

In the late 1970s the Chinese government launched a significant reform of the banking industry by establishing four wholly state-owned banks (the Big Four), which took control of all the lending functions of the People's Bank of China (the central bank). In 1994, three new wholly state-owned policy banks ${ }^{1}$ were established, and took over policy lending from the Big Four banks. In 1996, joint-stock commercial banks and city banks began to emerge. Though more types of banks were starting to emerge locally, the state-owned banks were not greatly concerned about the competition, due to the dominance of state ownership and the size of their own assets. In 2006, the Chinese government launched banking reforms for these state-owned banks in light of the international competition mandated by the World Trade Organization (WTO). The reforms were introduced on several fronts, including transferring non-performing loans to newly established asset-management companies, introducing strategic investors and public listing. All of these reforms aimed to transform the banks into business entities operating on a commercial basis, which has naturally affected the behaviour of bank executives and lending decisions.

Originally, bank loans mainly took the form of credit loans granted to SOEs at low interest rates and without any guarantees or collateral, in conformance with lending policy. These loans were one of the causes of a higher ratio of non-performing loans (NPLs). As this market-oriented economic reform deepened, banks became more aware of loan risks, and from the 1990s they increasingly demanded guarantees or collateral. According to a survey of 13 domestic banks between 2000 and 2005, the average collateral requirement for secured loans increased from $22 \%$ to $32 \%$ of all loans granted (Yang and Qian, 2008), of which land

\footnotetext{
${ }^{1}$ These are the State Development Bank, the Agricultural Development Bank of China and the Export and Import Bank of China.
} 
or buildings became the most acceptable form. Banks also demanded the equivalent value of fixed assets as collateral before granting loans, especially to privately controlled firms (Yeung, 2009).

In addition, SOEs were favoured over non-SOEs in granting these bank loans (Wei and Wang, 1997; Cull and Xu, 2003), with state-owned banks often lending to SOEs for political, employment and taxation purposes rather than just profitability. As discussed by Yeung (2009), for these banks (the Big Four SOCBs, policy banks, joint-stock commercial banks and city banks), the decision to grant loans was often determined by unofficial assessment criteria. SOEs tended to receive loans without pledging the necessary collateral because of state ownership and implicit government guarantees, while non-SOEs were expected to pledge collateral by securing their fixed assets to the equivalent value of the collateral required. In other words, banks made a rational decision to bias their lending against nonSOEs based on the higher risks and higher transaction and risk-evaluation costs.

\subsection{Hypothesis development}

The existing literature proposes explanations for the phenomenon observed in China of significant economic growth in the private sector in the presence of formal financing discrimination, and suggests that alternative financing channels based on relationships support the growth of the private sector (Allen et al., 2005; Chen et al., 2013). As information asymmetry and the agency problem are the main obstacles to firms' financing (Leland and Pyle, 1977; Sharpe, 1990; Sufi, 2007; Firth et al., 2009), firms have incentives to alleviate information asymmetry and conflicts of interest with banks by establishing connections with them.

One way to establish connections is to employ executives with previous work experience in banks. These executives may use their expertise and networks to facilitate a firm's access to external financing through the following ways. First, work experience in the banking sector allows executives to establish/maintain connections with their former employers or even wider connections in the banking industry. In this sense, these executives have acquired the necessary skills to effectively communicate with banks and negotiate loan terms. They also facilitate firm-specific information that is not publicly available or observable to be revealed and shared with banks. This will mitigate information asymmetry and reduce banks' monitoring costs, and lead to more effective monitoring and improved information transparency. Secondly, through their career paths, these executives bring professional knowledge (such as financing and investment) and sophisticated financial skills with them that allow them to adopt other financial decisions to facilitate firms' access to external 
financing. Moreover, it is notable that trustworthiness plays a key role in the intensive and complex process of communications, which is essential for the effective transfer of borrowers' confidential information. When a connection and trust have been established, banks have proprietary information on firms, and financial contracting based on relationships should occur because there is less information asymmetry and conflict of interest between the parties.

In addition, as argued by Shelifer and Vishny (1997), banks exert effective external governance in terms of scrutinizing firms' projects and creditworthiness when making lending decisions. In this line of research, Firth et al. (2009) and Chen et al. (2013) provide empirical evidence that banks use commercial judgments in allocating credit to private firms in China. Thus, due to reduced information asymmetry and conflicts of interest between firms and banks, banks can make more efficient scrutiny of loan applications and better evaluate firms' future earnings. Therefore, we expect that banks can make optimal lending decisions based on the profitability of firms with bank connections.

H1: Firms' bank connections strengthen the relationship between bank loan size and firm profitability.

In addition to firms' bank connections, firms would also like to hire executives/directors who have work experience in governments to establish close connections with government, and firms that do so are found to be more leveraged and face a lower cost of debt financing than their peers (Claessens et al., 2008; Li et al., 2008; Faccio, 2010; Qi et al. 2010; Houston et al., 2014). This is particularly true for non-SOEs in China, as they are often denied access to bank loans and are subject to heavy government regulations or "extralegal" fees. In such an environment, close ties to the government help them overcome these market and state failures and avoid ideological discrimination (Li et al., 2008). However, compared with the effects of firms' bank connections, political connections may have the opposite influence and be valuedestroying. Specifically, government officials exert significant pressure on local state-owned banks to extend credits and preferential treatment to politically connected firms. In this sense, banks are reluctant to make these politically based loans; thus political connections do not necessarily improve the quality of either corporate governance or information transparency in these politically connected non-SOEs. Though political connections may bring more bank loans to politically connected firms, these politically based loans are granted for political rather than economic reasons, regardless of firm profitability, and could cause capital misallocation (Zheng and Zhu, 2013). As this politically based lending is not aligned with 
banks' interests, banks are unlikely to exert effective monitoring, which may further weaken banks' lending decisions. Therefore, we construct the following hypothesis:

H2: Firms' political connections weaken the relationship between bank loan size and firm profitability.

\section{Data and variables}

\subsection{The sample selection}

The sample we use to conduct the empirical analysis is collected from the Bank Loan dataset of the Chinese Stock and Market Accounting Research database (CSMAR) from 2003 to 2010. As new accounting and auditing standards were applied to all listed firms in China in 2002, we start our sample from 2003. This Bank Loan dataset includes the information for each announcement, such as loan amount, interest rate, loan maturity, lending bank, whether the loan is guaranteed by a third party and whether the loan is secured by collateral.

To examine the influence of both bank and political connections on the bank lending decisions, we initially assemble 807 bank loan announcements. We then delete 10 contracts with missing information on the loan amounts, 25 contracts granted to non-SOEs in the financial industry and 23 contracts granted to non-SOEs flagged with ST or *ST ${ }^{2}$, leaving 749 loan contract observations. Then, matching with the data from the sub-database of balance sheets, cash-flow statements and income statements, we also delete those observations for which information on the corporate governance and firm characteristics of these non-SOEs is missing. We are left with 730 loan contract observations where a loan was granted to our sample firms. To avoid the influence of outliers, we also winsorize the top and bottom $1 \%$ of all continuous variables.

According to the China Securities Regulatory Commission (CSRC), Chinese listed firms are required to disclose those bank loans whose transaction is more than $10 \%$ of equity book value and those that are more than 10 million RMB. Therefore, a sample of bank loans we collect includes both large bank loans which are disclosed compulsorily and small loans which are disclosed voluntarily. These bank loans were granted to 185 listed non-SOEs and account for $16.78 \%$ of all 1102 listed non-SOEs by the end of 2010. A question which then naturally arises is to what extent this sample is representative of the population of all nonSOEs. To demonstrate the representativeness of our sample, we follow Huang et al. (2012) by comparing certain characteristics between our sample and all listed non-SOEs (Table 1).

\footnotetext{
${ }^{2}$ ST stands for Special Treatment and refers to listed firms that have already had negative net profits for two consecutive years. *ST refers to listed firms that already had negative net profits for three consecutive years and thus have the probability of being delisted from the stock exchanges.
} 
With regard to profitability, the average return on assets (ROA) and return on sales (ROS) for our sample are $3.77 \%$ and $8.46 \%$, respectively, which are quite comparable to $3.51 \%$ and $8.76 \%$ for all listed non-SOEs; the differences are insignificant. Leverage for our sample firms is $50.48 \%$, which is quite close to the level for all listed non-SOEs (49.48\%). We also observe that both employee number and largest shareholding do not significantly differ between our sample firms and all listed non-SOEs. Overall, our sample characteristics are not significantly different from the population of non-SOEs in terms of profitability, leverage, firm size or ownership structure.

Table 1. Comparison of firm characteristics between non-SOEs in our sample and all listed non-SOEs

\begin{tabular}{llll}
\hline & Our sample non-SOEs & All listed non-SOEs & Difference test (t-value) \\
\hline Return on assets (ROA) & $3.77 \%$ & $3.51 \%$ & $0.26 \%(0.98)$ \\
Return on sales (ROS) & $8.46 \%$ & $8.76 \%$ & $-0.30 \%(-0.47)$ \\
Leverage & $50.48 \%$ & $49.48 \%$ & $1.00 \%(0.17)$ \\
Employee number & 1516.0 & 2086.7 & $-570.7(-1.33)$ \\
Largest shareholding & $33.32 \%$ & $35.22 \%$ & $-1.90 \%(-1.25)$ \\
Observations & 730 & 1,102 & \\
\hline
\end{tabular}

\subsection{Measuring bank connections and political connections}

We manually collect information on the career paths and work experience of executives and directors (including CEO, Chairman and other executive directors) for each firm each year by searching press and online news resources, and combine this information with brief résumés provided by the CSMAR database. We consider a firm to have a bank connection if at least one executive has work experience in either commercial banks or investment banks. To make sure that bank-connected individuals influence corporate strategy effectively, we carefully identify their work positions and only consider governors, vice-governors, managers and vice-managers of banks or departments of banks. In our definition we consider all banks at different levels, such as headquarters, branches and sub-branches. In our sample, all executives with banking experience are former bankers and we find none of them are currently holding a senior position in any bank. In this sense, our bank connections can rule out a complicated situation of conflicts of interest that arise when a current banker is sitting on a firm's board.

In the spirit of Fan et al. (2007) and Chen et al. (2011a), we consider a firm to have a political connection if at least one executive is any of the following, formerly or currently: (1) government official; (2) military official; (3) member of the standing committee of the National People's Congress (NPC); or (4) member of the Chinese People's Political Consultative Conference (CPPCC). 
Empirically, we create a dummy variable, Bank, which equals 1 if a firm has bank connections and 0 otherwise. We also create a dummy variable, Political, which equals 1 if a firm has political connections and 0 otherwise. In the empirical analysis, while we almost exclusively rely on these dummy variables capturing the presence of either bank-connected or politically connected executives, we also conduct robustness tests using the proportion of bank-connected or politically connected executives/directors ${ }^{3}$. All variables, including those of key interest and control variables, are defined in Table 2.

Table 2. Variables and definitions

\begin{tabular}{|c|c|}
\hline Name of Variable & Definition of variable \\
\hline Loansize & Log of the amount of bank loans. \\
\hline Bank connections (Bank) & $\begin{array}{l}\text { A dummy variable equal to } 1 \text { if an executive/director (including the } \\
\text { chairman of the board, CEO and other directors) was a former officer } \\
\text { of a bank, and } 0 \text { otherwise. }\end{array}$ \\
\hline Political connections (Political) & $\begin{array}{l}\text { A dummy variable equal to } 1 \text { if an executive/director (including the } \\
\text { chairman of the board, CEO and other directors) was any of the } \\
\text { following formerly or currently: (1) government official; ( } 2 \text { military } \\
\text { official; (3) member of the standing committee of the National } \\
\text { People's Congress (NPC); ( } 4 \text { ) member of the Chinese People's } \\
\text { Political Consultative Conference (CPPCC); (5) member of All-China } \\
\text { Federation of Industry and Commerce (ACFIC). The variable is equal } \\
\text { to } 0 \text { otherwise. }\end{array}$ \\
\hline Return on assets (ROA) & Net income / Total assets. \\
\hline Firm_age (Firm age) & Natural log of years since the firm was established. \\
\hline Firm size (Size) & Natural log of firm total assets. \\
\hline Leverage & Total debts / Total assets. \\
\hline Tangibility (Tangible) & Tangible assets / Total assets. \\
\hline Cash-flow volatility (Volatility) & The volatility of cash flows for the previous three years. \\
\hline Employee & Natural log of number of employees. \\
\hline Independent director (Indep) & Ratio of independent directors to total directors. \\
\hline Duality & $\begin{array}{l}\text { A dummy variable equal to } 1 \text { if the CEO is also the chairman and } 0 \\
\text { otherwise. }\end{array}$ \\
\hline Bigfour & $\begin{array}{l}\text { A dummy variable equal to } 1 \text { if the lending bank is one of the Big } \\
\text { Four and } 0 \text { for other banks. }\end{array}$ \\
\hline Repeat & $\begin{array}{l}\text { A dummy variable equal to } 1 \text { if the loan is a repeat borrowing } \\
\text { obtained from a specific bank and } 0 \text { for the first borrowing. }\end{array}$ \\
\hline Executive age (Exeage) & $\begin{array}{l}\text { The age of the connected executives. If the firm is neither bank- } \\
\text { connected nor politically connected, this value is defined as the age of } \\
\text { the chairman. }\end{array}$ \\
\hline Executive tenure (Tenure) & $\begin{array}{l}\text { The number of years that the connected executives have held their } \\
\text { positions in the firms. If the firm is neither bank-connected nor } \\
\text { politically connected, this value is defined as the tenure of the } \\
\text { chairman. }\end{array}$ \\
\hline Executive education (Education) & $\begin{array}{l}\text { A dummy variable equal to } 1 \text { if the connected executive has a degree } \\
\text { of master or above and } 0 \text { otherwise. If the firm is neither bank- } \\
\text { connected nor politically connected, this value is defined as the } \\
\text { education level of the chairman. }\end{array}$ \\
\hline Bank ROA (BankROA) & ROA of lending banks. \\
\hline Bank board size (Bankboard) & Log of number of directors on boards of lending banks. \\
\hline
\end{tabular}

\footnotetext{
${ }^{3}$ According to Chen et al. (2011a), the effectiveness of independent directors in influencing corporate policy is debatable because they are not appointed voluntarily by firms but required to be on the board in accordance with the CSRC rule. Thus, we do not consider independent directors in our main empirical analysis.
} 


\subsection{Models and estimation}

We perform empirical analysis to test our hypotheses $\mathrm{H} 1$ and $\mathrm{H} 2$ by examining the effects of both types of connection on the relationship between bank loan size and firm profitability. In the spirit of the equations used by existing studies (Firth et al., 2009; Chen et al., 2013; Zheng and Zhu, 2013), we develop the following equation regarding the determinants of bank loan size, and include proxies for both types of connection as independent variables. Then, following the discussion that bank loans granted should depend on the borrowing firm's profitability (Firth et al., 2009; Zheng and Zhu, 2013), we use the sensitivity of newly granted bank loans to firms' profitability as the proxy for the bank's lending decision, where strong sensitivity indicates an optimal lending decision. The baseline model is expressed as follows:

$$
\begin{aligned}
\text { Loansize }_{i t}= & \alpha_{0}+\alpha_{1} \text { Connection }_{i t}+\alpha_{2} \text { Connection }_{i t} * \text { ROA }_{i t}+\alpha_{3} \text { ROA }_{i t} \\
& +\alpha_{4} \text { Firmage }_{i t}+\alpha_{5} \text { Size }_{i t}+\alpha_{6} \text { Leverage }_{i t}+\alpha_{7} \text { Tangible }_{i t} \\
& +\alpha_{8} \text {.olatility }_{i t}+\alpha_{9} \text { Employee }_{i t}+\alpha_{10} \text { Indep }_{i t}+\alpha_{11} \text { Duality }_{i t} \\
& +\alpha_{12} \text { Bigfour }_{i t}+\alpha_{13} \text { Repeat }_{i t}+\alpha_{14} \text { Exeage }_{i t}+\alpha_{15} \text { Tenure }_{i t} \\
& +\alpha_{16} \text { Education }_{i t}+\alpha_{17} \text { BankROA }_{i t}+\alpha_{18} \text { Bankboard }_{i t}+\varepsilon_{i t}
\end{aligned}
$$

where Loansize is the bank loan size, defined as the log of the amount of the newly granted bank loans. Connection is the indicator of our key variables, including Bank and Political. $R O A$ is return on assets, the proxy for firm profitability, calculated as the ratio of net income to total assets, and we include one interaction term between Connection and ROA to test the effect of previous work experience on banks' lending decisions. In this equation, we also control for other variables of firm, executive and bank characteristics which are defined in Table 2. We also include industry and year fixed effects in the regression estimation.

In the empirical analysis, we first separately enter the bank connection dummy and political connection dummy to examine their individual effect. We then put them together to test our main hypotheses, comparing their individual effects and examining which effect is more significant.

\section{Empirical results}

\subsection{Summary statistics}

Table 3 provides the summary statistics for the study sample period from 2003 to 2010, including all variables used for the univariate and multivariate tests. The summary shows that for all bank loan announcements we collected, the average log of bank loan amount is 17.48. With regard to both bank connections and political connections, we find that $17.26 \%$ of total observations have bank connections, and $40.41 \%$ have political connections. These indicate 
that among the 730 observations in our sample, there are $126(=730 * 17.26 \%)$ observations of firms which have bank connections and $295(=730 * 40.41 \%)$ observations of firms which have political connections. Moreover, in our sample, we also find that there are 29 observations of firms which have both bank connections and political connections. We also conduct the correlations between each pair of independent variables to make sure that none of them are highly correlated with each other. From the unreported correlation matrix, the correlation coefficients are all less than 0.25 , suggesting that multicollinearity is not a problem in the regression analysis.

Table 3. Summary statistics for all variables

\begin{tabular}{llllll}
\hline & Mean & Median & $\begin{array}{l}\text { Bottom } \\
\text { quartile }\end{array}$ & Upper quartile & Observations \\
\hline Loansize & 17.48 & 17.50 & 16.52 & 18.42 & 730 \\
Bank connections (Bank) & $17.26 \%$ & 0 & 0 & 0 & 730 \\
Political connections (Political) & $40.41 \%$ & 0 & 0 & 1 & 730 \\
Return on assets (ROA) & $3.77 \%$ & $2.96 \%$ & $1.01 \%$ & $5.32 \%$ & 730 \\
Firm_age (Firmage) & 1.72 & 2.07 & 1.09 & 2.30 & 730 \\
Firm size (Size) & 21.43 & 21.11 & 20.74 & 22.21 & 730 \\
Leverage & $50.48 \%$ & $51.95 \%$ & $41.68 \%$ & $66.52 \%$ & 730 \\
Tangible & $47.05 \%$ & $41.04 \%$ & $29.55 \%$ & $65.31 \%$ & 730 \\
Cash-flow volatility (Volatility) & 1.78 & 1.79 & 1.72 & 1.80 & 730 \\
Employee & 6.30 & 6.49 & 4.85 & 7.52 & 730 \\
Independent director (Indep) & $25.47 \%$ & $33.33 \%$ & $10.00 \%$ & $36.36 \%$ & 730 \\
Duality & $12.19 \%$ & 0 & 0 & 0 & 730 \\
Bigfour & $43.49 \%$ & 0 & 0 & 1 & 730 \\
Repeat & $68.09 \%$ & 1 & 0 & 1 & 730 \\
Exeage & 43.92 & 44 & 40 & 51 & 730 \\
Tenure & 2.26 & 1.87 & 1.67 & 3 & 730 \\
Education & $53.6 \%$ & 1 & 0 & 1 & 730 \\
BankROA & $1.08 \%$ & $0.97 \%$ & $0.32 \%$ & $1.75 \%$ & 730 \\
Bankboard & 2.56 & 2.64 & 2.39 & 2.70 & 730 \\
\hline Alt & & &
\end{tabular}

All variables are defined in Table 2.

Table 4 summarizes the distributions of the total 730 bank loans included in our sample according to year, industry, the number of banks that granted loans and number of non-SOEs that received the loans, and these distributions are reported in three panels separately. Panel A shows that more than $50 \%$ of total loans were granted after 2007, Panel B shows that most of the loans were granted to the firms from the manufacturing industry and Panel $\mathrm{C}$ shows that a majority of loans were granted by the Big Four banks. Panel D shows that more than $50 \%$ of banks granted only one bank loan during our sample and most of the firms in our sample have received less than five bank loans.

Table 4. Distributions of bank loans by year, industry, bank types and number of banks and number of non-SOEs

\begin{tabular}{lll}
\hline & Number of bank loans & $\%$ of the total sample \\
\hline Panel A: Distribution of bank loans by year & & \\
\hline 2003 & 90 & 12.33 \\
2004 & 52 & 7.12 \\
2005 & 26 & 3.56 \\
2006 & 34 & 4.66 \\
\hline
\end{tabular}




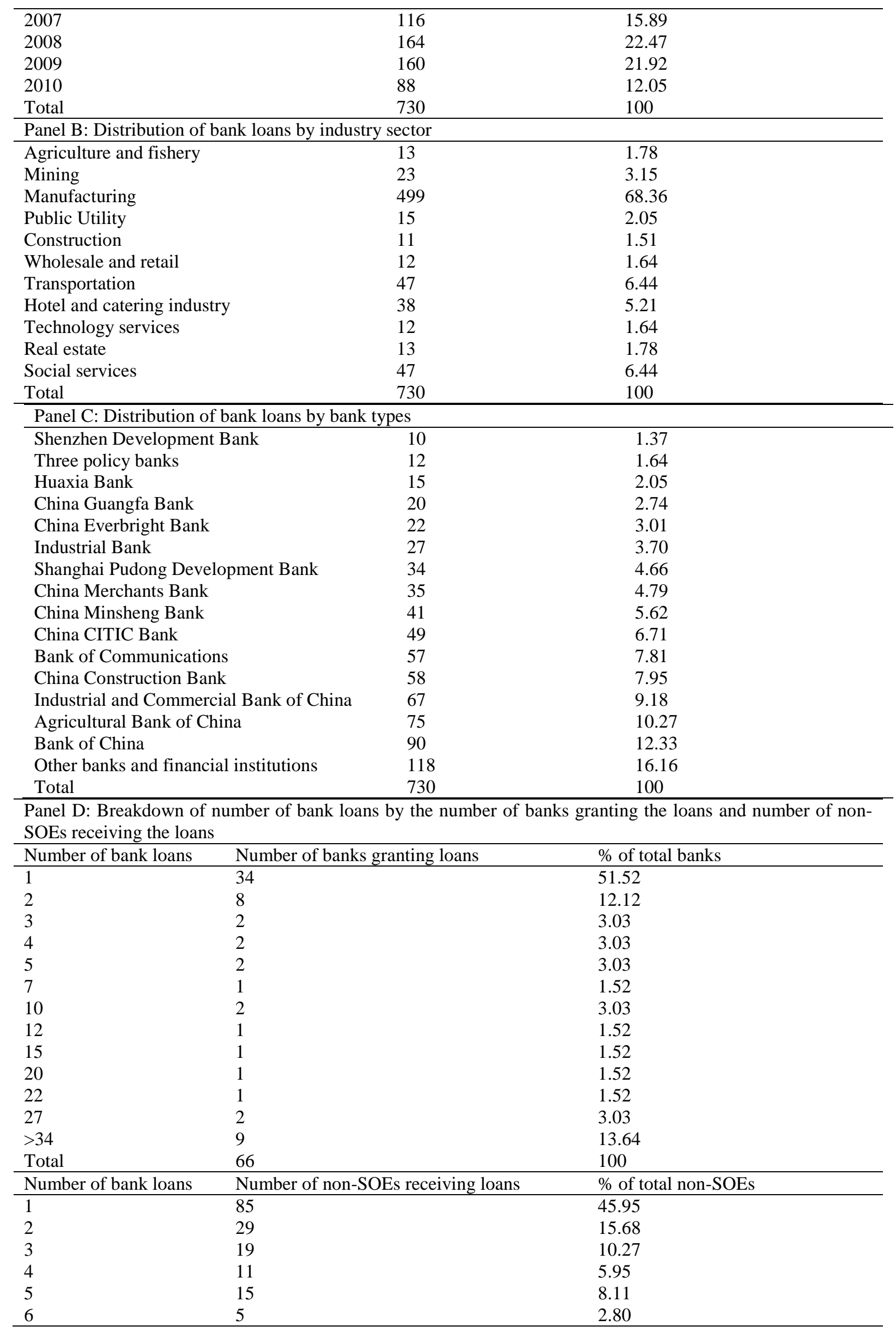




\begin{tabular}{lll}
\hline 8 & 3 & 1.62 \\
9 & 1 & 0.54 \\
10 & 3 & 1.62 \\
11 & 2 & 1.08 \\
12 & 3 & 1.62 \\
$>13$ & 9 & 4.86 \\
Total & 185 & 100 \\
\hline
\end{tabular}

This table presents information on the distributions of bank loans in our sample from 2003 to 2010. Panels A to $\mathrm{C}$ present the distributions of bank loans according to year, industry and bank types. Panel D presents information on the distributions of bank loans according to the number of banks that have granted loans and number of non-SOEs that have received bank loans in our sample from 2003 to 2010.

To provide some preliminary evidence for our hypotheses, Table 5 presents the univariate tests of bank loan size and other firm characteristics for firms with and without bank connections (Panel A), and with and without political connections (Panel B). The results in Panel A show that bank loan size is significantly higher for firms with bank connections than for those without. This result supports our hypothesis that bank connections can help firms obtain more bank loans. We further find that firms with bank connections have a higher leverage level, though the difference is insignificant. In Panel B, which focuses on political connections, we observe quite similar results for our key variables and firm characteristics, while the leverage level between firms with and without political connections is insignificant.

Table 5. Univariate tests of all variables

\begin{tabular}{|c|c|c|c|}
\hline \multicolumn{4}{|c|}{ Panel A: Difference tests between firms with and without bank connections } \\
\hline & With bank connections & Without bank connections & Difference tests \\
\hline Loansize & 18.55 & 17.25 & $1.30 * * *(2.51)$ \\
\hline ROA & $4.45 \%$ & $3.63 \%$ & $0.82 \%(1.51)$ \\
\hline Firmage & 1.78 & 1.71 & $0.07(0.91)$ \\
\hline Size & 21.04 & 21.50 & $-0.46 * * *(-4.53)$ \\
\hline Leverage & $52.09 \%$ & $50.15 \%$ & $1.94 \%(1.13)$ \\
\hline Tangible & $40.78 \%$ & $48.36 \%$ & $-7.58 \% * * *(-3.07)$ \\
\hline Volatility & 1.79 & 1.78 & $0.01(1.56)$ \\
\hline Employee & 6.41 & 6.29 & $0.12(0.78)$ \\
\hline Indep & $28.64 \%$ & $24.82 \%$ & $3.82 \% * *(2.33)$ \\
\hline Duality & $11.11 \%$ & $12.42 \%$ & $-1.31 \%(-0.41)$ \\
\hline Bigfour & $42.73 \%$ & $43.65 \%$ & $-0.92 \% *(-1.81)$ \\
\hline Repeat & $81.75 \%$ & $65.24 \%$ & $16.51 \% * * *(4.16)$ \\
\hline Exeage & 47.53 & 43.17 & $4.36 * * *(6.87)$ \\
\hline Tenure & 2.67 & 2.18 & $0.49 * * *(2.77)$ \\
\hline Education & 39.68 & 55.29 & $-15.61 * * *(-3.23)$ \\
\hline BankROA & $1.09 \%$ & $1.08 \%$ & $0.01 \%(0.17)$ \\
\hline Bankboard & 2.55 & 2.56 & $-0.01(-1.00)$ \\
\hline Observations & 126 & 604 & \\
\hline \multicolumn{4}{|c|}{ Panel B: Difference test between firms with and without political connections } \\
\hline & With political connections & Without political connections & Difference tests \\
\hline Loansize & 17.73 & 17.32 & $0.41 * *(2.06)$ \\
\hline ROA & $4.02 \%$ & $3.60 \%$ & $0.42 \%(1.04)$ \\
\hline Firmage & 1.87 & 1.62 & $0.25 * * *(4.55)$ \\
\hline Size & 21.31 & 21.51 & $-0.20 * *(-2.33)$ \\
\hline Leverage & $51.76 \%$ & $49.62 \%$ & $2.14 \%(1.31)$ \\
\hline Tangible & $42.93 \%$ & $49.85 \%$ & $-6.92 \% * * *(-3.65)$ \\
\hline Volatility & 1.79 & 1.77 & $0.02 * *(2.47)$ \\
\hline Employee & 6.09 & 6.46 & $-0.37 * * *(-3.31)$ \\
\hline Indep & $24.06 \%$ & $26.43 \%$ & $-2.37 \% *(-1.82)$ \\
\hline
\end{tabular}




\begin{tabular}{llll} 
Duality & $11.52 \%$ & $12.64 \%$ & $-1.12 \%(-0.45)$ \\
Bigfour & $44.72 \%$ & $42.23 \%$ & $2.49 \% *(1.89)$ \\
Repeat & $74.24 \%$ & $63.91 \%$ & $10.33 \% * * *(3.00)$ \\
Exeage & 46.33 & 42.27 & $4.06 * * *(7.70)$ \\
Tenure & 2.16 & 2.33 & $-0.17 *(-1.64)$ \\
Education & 38.31 & 62.29 & $-23.98 * * *(-6.54)$ \\
BankROA & $1.21 \%$ & $0.99 \%$ & $0.22 \% * * *(3.72)$ \\
Bankboard & 2.55 & 2.56 & $-0.01(-0.30)$ \\
Observations & 295 & 435 & \\
\hline All variables are defined in Table 2. ${ }^{*}, * *$ and $* * *$ indicate significance at the $10 \%, 5 \%$ and $1 \%$ level, \\
respectively.
\end{tabular}

\subsection{Bank connections, political connections and banks' lending decisions}

In this section, we perform regression analysis to examine how bank lending behaviour varies across firms with and without bank connections/political connections. The estimation results of equation (1) are shown in Table 6. Columns 1 and 2 focus on bank connections and political connections, separately, and column 3 combines them. Across three specifications, we find that the estimated coefficients of Bank are higher than those of Political, suggesting that bank connections have more significant effects on accessing bank loans relative to political connections.

In Table 6, the variables we are concerned about are the interaction terms. In particular in column 1, the coefficient on Bank*ROA is 0.77 , significant at the $1 \%$ level (t-value is 2.87 ). This result supports our hypothesis H1 that bank connections are able to encourage firmspecific information transfer and reduce the credit risk faced by banks, so that banks can access more proprietary information about non-SOEs. Bank-connected executives with financial skills can also help firms to adopt sophisticated financial decisions to facilitate more access to external bank loans and improve firm profitability. Thus banks can lend optimally to non-SOEs by better evaluating their profitability. In column 2, we observe that political connections exert an opposite effect on banks' lending decisions, reflected by the negative coefficient on Political*ROA. In column 3, which includes both bank connections and political connections, their effects on banks' lending decisions are consistent with those in the first two columns. Our findings are consistent with those reported by Zheng and Zhu (2013), who argue that lending based on political connections reduces the efficiency of banks' monitoring. The estimated coefficients on control variables are similar to those reported in previous tables.

Overall, the results from Table 6 provide supportive evidence for our hypotheses $\mathrm{H} 1$ and $\mathrm{H} 2$ that bank connections can enhance bank lending decisions while political connections distort banks' capital allocation. In general, we argue that, though both bank connections and 
political connections can facilitate access to more bank loans, they matter in different ways and result in different economic implications. Specifically, bank-connected executives have financial skills, and can reduce information asymmetry and potential credit risks, so that banks are encouraged to grant loans to financially healthier firms, especially those with bank connections that can make banks better informed. However, politically based lending is usually granted under political pressure, which is unrelated to firm profitability and less likely to be accompanied by bank monitoring.

Table 6. Effect of bank connections and political connections on bank lending decisions

\begin{tabular}{|c|c|c|c|}
\hline Dependent variable & & Loansize & \\
\hline Bank & $0.40 * * *(3.00)$ & & $0.42 * * *(3.22)$ \\
\hline Bank*ROA & $0.77 * * *(2.87)$ & & $0.80 * * *(2.90)$ \\
\hline Political & & $0.29 * *(2.01)$ & $0.34 * *(2.39)$ \\
\hline Political*ROA & & $-0.79 * *(-2.47)$ & $-1.51 * * *(-2.90)$ \\
\hline ROA & $1.42 * *(2.38)$ & $1.04 * *(2.08)$ & $1.42 * *(2.37)$ \\
\hline Firmage & $0.04 * * *(2.96)$ & $0.05 * * *(3.76)$ & $0.03 * * *(2.59)$ \\
\hline Size & $0.62 * * *(12.88)$ & $0.62 * * *(12.74)$ & $0.63 * *(13.09)$ \\
\hline Leverage & $-0.43 *(-1.78)$ & $-0.39(-1.61)$ & $-0.51 * *(-2.12)$ \\
\hline Tangible & $-0.26(-1.25)$ & $-0.27(-1.32)$ & $-0.20(-1.00)$ \\
\hline Volatility & $-0.19 * * *(-5.24)$ & $-0.20 * * *(-5.62)$ & $-0.18 * * *(-5.07)$ \\
\hline Employee & $0.13 * * *(3.60)$ & $0.15 * * *(4.17)$ & $0.13 * * *(3.56)$ \\
\hline Indep & $1.16 *(1.70)$ & $1.23 *(1.80)$ & $1.03(1.51)$ \\
\hline Duality & $-0.07(-0.47)$ & $-0.07(-0.51)$ & $-0.05(-0.35)$ \\
\hline Bigfour & $0.24 * *(1.96)$ & $0.06(0.57)$ & $0.33 * * *(2.57)$ \\
\hline Repeat & $0.48 * * *(4.73)$ & $0.44 * * *(4.33)$ & $0.52 * * *(4.97)$ \\
\hline Exeage & $0.04 * * *(6.30)$ & $0.05 * * *(7.22)$ & $0.04 * * *(5.73)$ \\
\hline Tenure & $0.02(0.62)$ & $0.05(1.43)$ & $0.03(0.99)$ \\
\hline Education & $0.04(0.37)$ & $0.02(0.16)$ & $0.03(0.36)$ \\
\hline BankROA & $6.47(1.17)$ & $7.99(1.44)$ & $6.86(1.24)$ \\
\hline Bankboard & $0.01(0.02)$ & $0.28(0.60)$ & $0.11(0.25)$ \\
\hline Constant & $2.77 *(1.77)$ & $1.80(1.13)$ & $2.26(1.43)$ \\
\hline Industry fixed effects & Included & Included & Included \\
\hline Year fixed effects & Included & Included & Included \\
\hline Adjusted $\mathrm{R}^{2}$ & 0.40 & 0.38 & 0.39 \\
\hline Observations & 730 & 730 & 730 \\
\hline
\end{tabular}

\subsection{Additional evidence}

\subsubsection{Industrial and regional variations}

As the objective of firms in building bank or political connections is to justify their existence and overcome market failure under the poor institutional environment, the effects of both bank and political connections depend to a large degree on the extent of the government's industry-supporting policies and levels of market development. If bank and political connections are effective in sheltering firms from ideological discrimination, their 
effects will be expected to diminish if firms are operating in industries that receive support through government policy or in regions with relatively developed markets.

Firms in our sample operate in different industries and regions, and thus are subject to different market conditions with respect to government policy and market development. On the one hand, every five years the Chinese government announces a Five Year Plan specifying that some specific industries will be more supported or favoured by government policy. As our sample ranges from 2003 to 2010, which covers the tenth (2001 to 2005) and the eleventh (2006 to 2010) Five Year Plans, we carefully identify the supported industries during the period of each plan, and the remainder are identified as less supported industries (See Appendix 1 for detailed classification). On the other hand, economic development varies across provincial regions and government retains significant control over the economy in less developed regions. In this study, we use the market development index filed by Fan et al. (2011) to measure the level of regional development, and a higher value of the market development index indicates a higher level of regional development. Therefore, we expect that firms from non-supported industries or less developed regions may have more incentives to employ connected executives in order to be favourably treated. We therefore take advantage of this difference in industry policy and market development levels to investigate where connections are more important to firms' bank loan finance.

Empirically, we partition our full sample into subsamples based on whether the industry is supported and the median value of the market development index. Then, we re-estimate the main regression for these subsamples and report the results in Table 7. Overall, we find that the expected coefficients of our key interaction variables still hold for the sample of firms from less supported industries and less developed regions. These results lend support to our main hypothesis that bank connections and political connections are effective in helping firms to access external bank loans, but they lead to opposite patterns of capital allocation efficiency, especially for those firms that face some discrimination in obtaining external finance.

Table 7. Effect of connections on bank lending decisions across industries and regions

\begin{tabular}{|c|c|c|c|c|}
\hline \multicolumn{5}{|c|}{ Dependent variable is Loansize } \\
\hline & $\begin{array}{l}\text { More supportive } \\
\text { industry }\end{array}$ & $\begin{array}{ll}\text { Less supportive } \\
\text { industry }\end{array}$ & $\begin{array}{l}\text { More developed } \\
\text { regions }\end{array}$ & Less developed regions \\
\hline Bank & $\begin{array}{l}0.20 \\
(1.10)\end{array}$ & $\begin{array}{l}0.47 * * \\
(1.99)\end{array}$ & $\begin{array}{l}0.22 * * * \\
(2.92)\end{array}$ & $\begin{array}{l}0.51 * * * \\
(2.90)\end{array}$ \\
\hline Bank*ROA & $\begin{array}{l}0.95 \\
(1.00)\end{array}$ & $\begin{array}{l}1.49 * * * \\
(3.55)\end{array}$ & $\begin{array}{l}0.55^{* * * *} \\
(2.61)\end{array}$ & $\begin{array}{l}6.07 * * \\
(2.11)\end{array}$ \\
\hline Political & $\begin{array}{l}0.01 \\
(0.00)\end{array}$ & $\begin{array}{l}0.48^{*} \\
(1.95)\end{array}$ & $\begin{array}{l}0.30^{*} \\
(1.80)\end{array}$ & $\begin{array}{l}0.85^{* * *} \\
(2.85)\end{array}$ \\
\hline Political*ROA & -3.38 & $-1.78 * * *$ & -0.99 & $-11.57 * * *$ \\
\hline
\end{tabular}


This table reports the results of bank connections and political connections on bank loan finance in less supported versus more supported industries and in more developed versus less developed regions. Other control variables are also included in the regressions. Variables are defined as in previous tables.

${ }^{\mathrm{a}}$ and ${ }^{\mathrm{b}}$ are F-statistics values of Chow tests, revealing the significance of the difference in the coefficients on the Bank*ROA and Political *ROA between firms from two subsamples.

T-statistics (in parentheses) are computed using robust standard error clustered by firm. *, ** and *** indicate significance at the $10 \%, 5 \%$ and $1 \%$ levels, respectively.

\subsubsection{Channels through which both connections work ${ }^{4}$}

In our main hypothesis development, we argued that bank connections are helpful in mitigating information asymmetry, lead firms to better access external bank loans and can improve capital allocation efficiency, while political connections can lead firms to better access external bank loans through government intervention, which may reduce capital allocation efficiency. If our arguments are valid, we expect to see that the effect of bank connections is more pronounced in firms with a higher level of information asymmetry, and the effect of political connections is more pronounced in firms located in regions with a lower level of law enforcement. In this section, we aim to provide direct empirical evidence to validate our arguments.

First, following Brennan and Subrahmanyam (1995), we use the number of analysts following a firm to measure the level of a firm's information asymmetry, and a larger number of analysts indicates a lower level of information asymmetry. Second, we use the ranking indicator of enforcing contracts provided by the Doing Business in China 2008 (World Bank Group) to measure the level of law enforcement. It is noted that this indicator is measured at the capital city level of each province, and we take these values of indicators as the measure of law enforcement at the provincial level ${ }^{5}$. Then, we divide our full sample into two subsamples based on the median value of information asymmetry and the median value of law enforcement, and re-estimate the main regressions for these subsamples.

The results reported in Table 8 confirm our previous discussions. For example, when we compare the results from the first two columns, we find that the coefficients of Bank*ROA are positive and significantly higher for firms with a high level of information asymmetry.

\footnotetext{
${ }^{4}$ We thank the reviewer for suggesting this test.

${ }^{5}$ We also use one composite index of the market development index by Fan et al. (2011), the legal environment composite index, to measure the level of law enforcement. As the ranking of provinces is the same based on either the market development index or the composite index, we obtain the same results as those reported in the last two columns in Table 7. These results are also consistent with our expectation that the influence of political connections is more significant in regions with a lower level of law enforcement.
} 
We also find that the effect of political connections is significantly higher for firms located in regions with a low level of law enforcement. Overall, the evidence from both the information asymmetry and law enforcement perspectives confirms our main hypothesis that bank connections are able to reduce the information asymmetry between borrowing firms and banks, which can lead to more favourable bank loan finance and more efficient capital allocation by banks. However, political connections help firms to better access external bank loans through government intervention, and this effect is more pronounced in regions with low law enforcement, which can lead to lower capital allocation efficiency.

Table 8. Effect of connections on bank lending decisions across information asymmetry and law enforcement

\begin{tabular}{lllll}
\hline Dependent variable is Loansize & \multicolumn{3}{l}{} \\
& $\begin{array}{l}\text { High information } \\
\text { asymmetry }\end{array}$ & $\begin{array}{l}\text { Low information } \\
\text { asymmetry }\end{array}$ & $\begin{array}{l}\text { High } \\
\text { enforcement }\end{array}$ & $\begin{array}{l}\text { law } \\
\text { enforcement }\end{array}$ \\
\hline Bank & $0.65 * *(3.08)$ & $0.24(1.42)$ & $0.32 * * *(2.88)$ & $0.87 * * *(2.91)$ \\
Bank*ROA & $5.90 * *(2.94)$ & $0.51 *(1.77)$ & $0.51 *(1.95)$ & $1.16 * * *(2.95)$ \\
Political & $0.58 * *(2.57)$ & $0.20 * *(2.11)$ & $1.05(0.58)$ & $0.24 * *(2.05)$ \\
Political*ROA & $-4.05(-1.43)$ & $-1.34 * * *(-2.61)$ & $-0.56(-0.64)$ & $-5.82 * *(-2.03)$ \\
Chow tests & & $4.23 * *$ a & & $5.23 * *$ b \\
Adjusted R & 0.42 & 0.50 & 0.46 & 0.38 \\
Observations & 389 & 341 & 381 & 349 \\
\hline
\end{tabular}

This table reports the results of bank connections and political connections on bank loan finance in firms with high versus low information asymmetry, and high versus low law enforcement. Other control variables are also included in the regressions. Variables are defined as in previous tables.

${ }^{a}$ and ${ }^{b}$ are F-statistics values of Chow tests, revealing the significance of the difference in the coefficients on the Bank $* R O A$ and Political $* R O A$ between firms from two subsamples.

T-statistics (in parentheses) are computed using robust standard error clustered by firm. *, ** and *** indicate significance at the $10 \%, 5 \%$ and $1 \%$ levels, respectively.

\subsubsection{Firm shareholder reaction to bank loan announcements}

A natural extension would be to examine the financial implications of both bank and political connections on firm value, reflected in market reactions, and to provide complementary evidence. If banks extend loans to firms with bank connections, this will provide a strong signal to the market that the commitment is credible and the borrowing firms are of better quality. Thus, shareholders will value loan contracts with these firms more highly than those without. However, politically based lending may not be beneficial to firm shareholders, as it is argued that political connections are a rent-seeking tool to extract private benefits (Chen et al., 2011a), and could cause capital misallocation by banks, which will lead to less efficient investment by firms (Zheng and Zhu, 2013). In this sense, shareholders may put a lower value on politically based lending.

Thus, in this section we apply an event-study method to investigate the effects of bank connections and political connections on the market value placed by investors. Specifically, the announcement effect is measured by the market-adjusted cumulative abnormal returns 
(CARs) around the bank-loan announcements using the market-adjusted excess return model. We choose a three-day event window (i.e., $-1,+1$ ), and 230 days as the estimation window (i.e., -240, -10).

To apply the CARs to measure the market reaction accurately, we require all shares in our sample to have trading information available from 240 days before the bank-loan announcements. Thus, we delete 85 observations from our original sample because of unavailable trading information. To isolate the market reaction to bank-loan announcements, we also delete bank-loan observations where a major event happened during our estimation window, including split-share reform (43), chairman or CEO turnover (18) and mergers and acquisitions announcements (6). Ultimately, we have 578 bank-loan observations for our analysis in this section, and 578 matching CARs observations in total. Empirically, we regress CARs around bank-loan announcements against a set of firm characteristics.

As shown in Table 9 Panel A, the coefficient on Bank is positive and statistically significant at the 5\% level (t-value is 2.28 ) in column 1 . However, in column 2, which considers political connections, we find that Political is significantly negatively related to CARs. In column 3, where we combine both Bank and Political, the estimated coefficients of both variables are quite similar to their individual estimations in the first two columns.

These results complement our previous findings. In summary, through reducing information asymmetry, bank connections facilitate efficient capital allocation and receive favourable market reactions. However, lending based on political connections shows a negative effect on market reactions, which echoes the findings of Zheng and Zhu (2013), because political connections may induce capital misallocation and inefficient investment. Thus, our previous results, as well as the results from Table 8, confirm our main hypothesis that bank connections differ from political connections in terms of the mechanisms through which they affect firm value.

\subsubsection{Bank shareholder reaction to bank loan announcements}

The above analysis shows that firm shareholders respond positively to bank-loan announcements concerning firms with bank connections. A natural question would be whether this is due to a wealth transfer from banks to firms. We then examine how bank shareholders react to these bank loan announcements. On the one hand, banks can reduce their monitoring costs and improve their monitoring ability for lending to firms with bank connections, so bank shareholders may feel confident about the safety of their lending and place more value on these loans. On the other hand, political pressure forces banks to make politically based lending, which may not necessarily be consistent with bank shareholders' 
interests. Moreover, such politically based lending may also lead to huge non-performing loans in China (Zheng and Zhu, 2013). In this sense, bank shareholders may discount the value of lending to firms with political connections.

We also use the event-study method in this section to examine the investor reaction to these bank loan announcements. From the initial 730 bank loan announcements, we first delete 99 observations because of unavailable trading information, either because lending banks are not listed on the stock exchange, or because there is not enough trading information for listed banks to calculate CARs. We also delete 65 observations to exclude contamination by other major events, leaving 566 observations for empirical analysis. Empirically, we regress the three-day CARs of bank shares around bank loan announcements against a set of bank characteristics.

In Table 9 Panel $\mathrm{B}$, which focuses on bank shareholder reactions, we observe quite similar results to those reported in Panel A with respect to bank connections. In particular, the estimated coefficients on Bank are both positive and statistically significant at the 5\% level, while the coefficients on Political are both negative and statistically significant at the 5\% level. These results indicate that bank shareholders respond positively when banks extend loans to firms with bank connections, but negatively when banks extend loans to firms with political connections. Overall, these results are consistent with our predictions that lending decisions towards non-SOEs with bank connections are enhanced, while lending decisions towards non-SOEs with political connections are further distorted.

Table 9. The effects of bank connections and political connections on CARs

\begin{tabular}{lcc}
\hline \multicolumn{2}{l}{ Panel A: Dependent variable is the CARs $(-1,+1)$ for firm shareholders around bank-loan announcements } \\
\hline Bank & $0.005^{* *}(2.28)$ & $0.006^{* *}(2.06)$ \\
Political & $-0.022 * * *(-6.95)$ & $-0.020^{* * *}(-6.82)$
\end{tabular}

Control variables are firm-level characteristics, including return on assets, firm size, tangible assets, board size, independent-director ratio, CEO duality, CEO age, CEO tenure, bank loan size, lending bank type and industry fixed effects.

$\begin{array}{llll}\text { Adjusted } \mathrm{R}^{2} & 0.14 & 0.13 & 0.14\end{array}$

$\begin{array}{llll}\text { Observations } & 578 & 578 & 578\end{array}$

Panel B: Dependent variable is the CARs $(-1,+1)$ for bank shareholders around bank-loan announcements

Bank $0.013 * *(2.04) \quad 0.013 * *(2.45)$

Political $\quad-0.012 * *(-2.00) \quad-0.012 * *(-2.05)$

Control variables are bank-level characteristics, including return on assets, bank size, board size, independentdirector ratio, bank loan size, lending bank type and industry fixed effects.
Adjusted $\mathrm{R}^{2}$
0.13
0.13
0.15
Observations
566
566
566

This table reports the results of the market reaction to bank loan announcements from the perspective of both firm shareholders and bank shareholders. The dependent variable is the three-day CARs of both firm shares and bank shares around bank loan announcements. Control variables are measured using the values at the end of the year before the year of bank loan announcements.

The T-statistics (in parentheses) are computed using robust standard error clustered by firm. ** and *** indicate the significance levels at $5 \%$ and $1 \%$, respectively. 


\subsubsection{Connections and other bank loan contract terms}

In the previous analysis, we have explored whether and how bank connections and political connections affect the bank loan size and capital allocation efficiency (measured by the relationship between bank loan size and ROA). As there are other terms in a bank loan contract, such as interest rate, maturity and whether the collateral is required, we aim to provide evidence on whether and how connections affect other terms, to further our understanding about the effect of connections on bank lending decisions. Empirically, we replace the dependent variable in equation (1) with a dummy variable for collateral requirement, debt maturity and interest rate, and the estimation results are reported in Table 10. As shown in the first column, we find that both connections can reduce the probability of pledging collateral to obtain bank loans, indicating that both connections help firms to reduce financing costs. The larger coefficient of Bank compared with that of Political also suggests that the effect of bank connections on reducing financing costs is more significant than that of political connections. In column 2, we find that political connections are helpful for obtaining more short-term loans, which is consistent with the evidence provided by Liu et al. (2016), while bank connections facilitate long-term loans, though the effect is insignificant. In column 3, we find that neither connection has a significant effect on interest rate level. The possible explanation is that during our sample period, the interest rate on bank loans is still relatively regulated by the government and banks have less discretion to determine the interest rate based on the quality of borrower. Overall, these additional results provide further evidence supporting our main finding that bank connections have a greater impact compared with political not only on accessing bank loans but also on debt maturity and collateral requirement.

Table 10 The effect of connections on other bank loan contract terms

\begin{tabular}{llll}
\hline Dependent variable & Collateral & Debt maturity & Interest rate \\
\hline Bank & $-0.67 * *(-2.49)$ & $0.19(1.09)$ & $-0.34(-0.77)$ \\
Political & $-0.43 * *(-2.21)$ & $-0.64 * * *(-3.40)$ & $0.36(0.73)$ \\
Other control variables from equation (1) are included in all regressions & \\
Adjusted/Pseudo $\mathrm{R}^{2}$ & 0.14 & 0.06 & 0.19 \\
Observations & 730 & 574 & 151 \\
\hline This table reports the effects of bank connections and political connections on collateral requirement, debt \\
maturity and interest rate. All the variables are defined as in Table 2. \\
T-statistics (Z-statistics) (in parentheses) are computed using robust standard error clustered by firm. ** and *** \\
indicate significance at the 5\% and 1\% levels, respectively.
\end{tabular}

\subsubsection{Other tests}

If our main argument, that bank connections are able to alleviate information asymmetry with banks and reduce banks' monitoring costs, is valid, then we will expect that firms with bank connections are more likely to receive loans for the first time from banks. To provide 
empirical evidence to verify our expectation, we re-estimate equation (1) by limiting the empirical sample to those that are first loan applications. We use the following steps to construct our empirical sample. First, from our main sample used in the previous analysis, we drop those for repeated loans. Secondly, from the Bank Loan dataset in the CSMAR, we also collect unsuccessful bank loan announcements (which only reflect the intention of seeking a loan but without the eventual granting of a loan) and limit it to first-time loan applications made by our sample of non-SOEs to a particular bank during our sample period from 2003 to 2010. Then, we combine these bank loan announcements together to form the empirical sample. To conduct regression analysis, we create a new dependent variable for this analysis, First, which is defined as a dummy variable equal to 1 if the loan is successfully granted and 0 if the loan is rejected. From the unreported results, we observe that the estimated coefficients on Bank and Political, individually and jointly, are all positive and statistically significant, indicating that firms with either bank connections or political connections are more likely to receive loans for the first time from banks, and that bank connections are more important than political connections, reflected by the magnitude and significance of estimated coefficients. However, caution should be taken when interpreting our results because some firms might have applied for the loans before 2003 (which is the start of our sample), and the first loan applications we mentioned above are not actually the real first loan application.

So far, our analysis focuses on the association between a firm's bank connections and loans granted by all banks. We thus have an additional concern over whether the effect of bank connections on obtaining bank loans may be more pronounced in the case of banks in which an executive used to work. Since we have argued that bank-connected executives may help firms reduce information asymmetry with banks, we thus conjecture that firms that are about to negotiate loans with banks can be more direct and influential when the bankconnected executive used to work at the bank with which the loan is being negotiated. In fact, in our sample of 126 bank loans granted to firms with bank connections, there are 70 bank loans granted by a former employer and 56 bank loans granted by other banks. The test in this section can also confirm the validity of our main argument. To conduct the empirical analysis, we focus on the subsample with bank-connected firms only and create a new variable. This variable is Lendingbank, which equals 1 if the loan is provided by the executive's former employer banks and 0 otherwise. We then re-estimate equation (1) by replacing Bank dummy with this new variable. The unreported results show that the estimated coefficient of Lendingbank is 0.04 , and statistically significant at the 5\% level. This result indicates that through mitigating information asymmetry, bank-connected firms are able to 
receive more loans from the banks where the firm's executives used to work, compared with the loans they receive from other banks.

In our previous analysis, we consider both bank connections and political connections together in the same regression. We also notice that during our sample, there are 29 observations with both bank connections and political connections. Thus a natural concern is that the observed effects of both connections in the previous tables could be contaminated by including these overlaps between bank connections and political connections. To address this concern, we repeat all of the previous analysis by excluding these 29 observations and we find that the results are quantitatively similar to those reported in the previous tables, which further confirms the robustness of our main results.

\subsection{Endogeneity issue}

Our main analysis may face a potential concern over endogeneity due to selection bias, since bank-connected or politically connected executives are not randomly distributed among our sample firms. In other words, a firm may appoint a bank-connected or politically connected executive when the firm is considering entering external capital markets. Moreover, whether to establish bank connections or political connections may also be determined by banks' lending decisions. Thus, the association between the presence of bank connections/political connections and bank lending decisions partially stems from reverse causality. In addition, firms with either bank connections or political connections might have other firm-specific characteristics unaccounted for in our model that affect both the connection status and bank loan finance. In other words, firms' bank connections and political connections might be correlated with other unobserved variables which will potentially bias the results. Although it is difficult to rule out the endogeneity issue completely, we attempt to minimize endogeneity concerns in three ways.

First, we apply the Heckman (1979) two-step procedure and estimate treatment effect regressions to correct for endogeneity, which has been used by Villalonga and Amit (2006), Chen et al. (2011b), and Wu et al. (2012). The first stage of the procedure involves a probit analysis where a bank (political) connection dummy is regressed against the same control variables from the bank loan equation. To meet the exclusion restrictions, we also include three variables that we do not include in the second-stage regression, by examining the Chinese institutional settings. The first two variables are Industry and Region, which we used in Table 7 to divide the full sample into subsamples. Specifically, Industry is a dummy variable equal to 1 for firms from more supported industries and 0 otherwise, and Region is a dummy variable equal to 1 for firms located in more developed regions and 0 otherwise. The 
third variable is the log of the amount of bank loans, which is included to test for a potential reverse causation. We obtain the inverse mills ratio (Lambda) from the first stage and include it as an independent variable in the second stage regression analysis of bank loan finance. We report the results of the first stage in Panel A of Table 11, and report the variables of interest of the second stage in Panel B of Table 11. First, from the first stage we find that firms from less supported industries are likely to establish bank connections, while firms from less developed regions are likely to establish political connections. Then in the second-stage results, we observe that across three specifications, the Lambda are all significantly negative, indicating that unobserved variable bias and the endogeneity issue might exist in the previous analysis. After correcting for these endogeneity issues, bank connections can also enhance banks' lending decisions while political connections may weaken the incentive of banks to grant loans to financially healthier firms.

Secondly, if an executive with either bank connections or political connections is appointed to facilitate bank loan finance, the deal is likely to be announced shortly after this executive's appointment. Therefore, following the method applied by Huang et al. (2014), we limit our empirical sample to observations that are less prone to endogeneity bias by excluding observations in which a bank or politically connected executive's tenure is less than three years. Our results remain robust. For the sake of brevity, we do not report the results here.

Table 11. Effect of connections on bank lending decisions (Heckman two-stage analysis)

\begin{tabular}{|c|c|c|}
\hline \multicolumn{3}{|c|}{ Panel A: The first stage of Heckman } \\
\hline & Bank connections & Political connections \\
\hline $\mathrm{ROA}$ & $3.15(1.53)$ & $2.61(1.58)$ \\
\hline Firmage & $0.05(1.51)$ & $0.22 * * *(5.33)$ \\
\hline Size & $-0.64 * * *(-4.08)$ & $-0.28 *(-1.74)$ \\
\hline Leverage & $1.96 * * *(2.81)$ & $2.84 * * *(3.68)$ \\
\hline Tangible & $-1.30 * *(-2.22)$ & $0.29(0.45)$ \\
\hline Volatility & $0.12(0.67)$ & $0.66 * * *(4.30)$ \\
\hline Employee & $0.04(0.44)$ & $-0.55 * * *(-4.65)$ \\
\hline Indep & 2.51(1.43) & $5.58 * * *(2.57)$ \\
\hline Duality & $-0.40(-0.97)$ & $-0.84(-1.62)$ \\
\hline Bigfour & $4.52 * * *(4.44)$ & $8.03 * * *(6.01)$ \\
\hline Repeat & $-1.09 * * *(-3.53)$ & $-1.12 * * *(-3.83)$ \\
\hline Exeage & $0.09 * * *(4.05)$ & $0.10 * * *(4.41)$ \\
\hline Tenure & $0.27 * * *(2.96)$ & $-0.31 * * *(-3.15)$ \\
\hline Education & $0.02(0.30)$ & $0.02(0.87)$ \\
\hline BankROA & $3.03(0.19)$ & $5.83 * * *(3.31)$ \\
\hline Bankboard & $-4.33 * * *(3.10)$ & $4.74 * * *(3.19)$ \\
\hline Industry & $-0.56 * *(-2.03)$ & $0.31(1.11)$ \\
\hline Region & $-0.08(-0.29)$ & $-0.72 * *(-2.34)$ \\
\hline Loansize & $5.80 * * *(2.84)$ & $7.78 * * *(2.60)$ \\
\hline Constant & $12.98 * * *(2.63)$ & $-19.77 * * *(-3.86)$ \\
\hline Pseudo $\mathrm{R}^{2}$ & 0.37 & 0.59 \\
\hline
\end{tabular}




\begin{tabular}{|c|c|c|c|}
\hline Observation & 730 & 73 & \\
\hline \multicolumn{4}{|c|}{ Panel B: The second stage of the Heckman and the dependent variable is Loansize } \\
\hline Bank & $0.09(1.61)$ & & $0.11 *(1.78)$ \\
\hline Bank*ROA & $0.85 * *(1.99)$ & & $0.91 * *(2.07)$ \\
\hline Political & & $0.11(0.76)$ & $0.08(0.60)$ \\
\hline Political*ROA & & $-0.07 * *(-2.04)$ & $-0.45 * *(-2.28)$ \\
\hline Lambda $_{\text {Bank }}$ & $-1.58 * * *(-4.76)$ & & $-1.11 * * *(-3.31)$ \\
\hline Lambda Political $_{\text {a }}$ & & $-2.93 * * *(-7.29)$ & $-2.53 * * *(-6.21)$ \\
\hline \multicolumn{4}{|c|}{ Control variables from the bank loan finance equation are also included in each regression. } \\
\hline Adjusted $\mathrm{R}^{2}$ & 0.41 & 0.42 & 0.46 \\
\hline Observations & 730 & 730 & 730 \\
\hline \multicolumn{4}{|c|}{$\begin{array}{l}\text { Panel A and Panel B of this table reports the Heckman two-stage analysis results of bank connections and } \\
\text { political connections on bank loan finance after correcting for possible selection bias. Lambda } \text { Bank } \text { and } \\
\text { Lambda } a_{\text {Political }} \text { are inverse mills ratios obtained from the first stages. Variables are defined as in previous tables. } \\
\text { T-statistics (in parentheses) are computed using robust standard error clustered by firm. } *{ }^{* *} \text { and } * * * \text { indicate } \\
\text { significance at the } 10 \%, 5 \% \text { and } 1 \% \text { levels, respectively. }\end{array}$} \\
\hline
\end{tabular}

Thirdly, we address the endogeneity issue using the propensity score matching method, which is consistent with Faccio et al. (2006). In the matching process, for each observation in the treatment sample (i.e., those observations with connections), we identify an observation in the control sample (i.e., those observations without connections) with the same/nearest propensity score of firm characteristics including firm size, leverage, tangibility, volatility, employment, and board independence. As we are concerned about both bank connections and political connections, we conduct the matching process two times for each connection. This procedure leads to 180 observations when we match on the bank connections and 356 observations when we match on the political connections. When we consider both connections in the same regression, we merge these two matching samples and the sample size is 476 . The slight difference in the size of the merged sample is due to the fact that some observations in the control samples are overlapped. First, to validate our matching process, we conduct the difference tests of these firm characteristics between connected firms and non-connected firms and report the results in Panels A and B of Table 12. We find that the differences of these firm characteristics are not significant. Then, we report the regression results using the matching samples in Panel $\mathrm{C}$ of Table 12. The estimated coefficients of the interaction terms are significant which are consistent with our main findings. The results suggest that after controlling for the endogeneity issue using the propensity score matching method, bank connection enhances the positive relationship between bank loan size and profitability and political connection weakens the positive relationship between bank loan size and profitability.

Table 12. Effect of connections on bank lending decisions (Propensity score matching method) Panel A: Difference tests of firm characteristics between firms with and without bank connections

Bank connections No bank connections Difference (t-value)




\begin{tabular}{|c|c|c|c|}
\hline Size & 21.08 & 21.06 & $0.02(0.25)$ \\
\hline Leverage & $51.83 \%$ & $52.25 \%$ & $-0.42 \%(0.22)$ \\
\hline Tangible & $41.76 \%$ & $39.58 \%$ & $2.18 \%(0.83)$ \\
\hline Volatility & 1.72 & 1.79 & $-0.07(-0.34)$ \\
\hline Employee & 6.26 & 6.36 & $-0.10(-0.84)$ \\
\hline Indep & $29.16 \%$ & $27.47 \%$ & $1.69 \%(0.91)$ \\
\hline \multicolumn{4}{|c|}{ Panel B: Difference tests of firm characteristics between firms with and without political connections } \\
\hline & Political connections & No political connections & Difference (t-value) \\
\hline Size & 21.53 & 21.49 & $0.04(0.36)$ \\
\hline Leverage & $48.59 \%$ & $49.82 \%$ & $-0.23 \%(-0.63)$ \\
\hline Tangible & $45.87 \%$ & $50.33 \%$ & $-4.46 \%(-0.91)$ \\
\hline Volatility & 1.73 & 1.85 & $-0.12(-0.87)$ \\
\hline Employee & 6.15 & 6.29 & $-0.14(-1.39)$ \\
\hline Indep & $27.92 \%$ & $25.58 \%$ & $2.34 \%(1.47)$ \\
\hline \multicolumn{4}{|c|}{ Panel C: Propensity score matching method regression results } \\
\hline Bank & $0.02(0.74)$ & & $-0.01(-0.53)$ \\
\hline Bank*ROA & $0.15 * *(2.02)$ & & $0.09 *(1.83)$ \\
\hline Political & & $0.01(1.46)$ & $0.01(0.20)$ \\
\hline Political*ROA & & $-0.11 * * *(-2.66)$ & $-0.10 * * *(-2.90)$ \\
\hline \multicolumn{4}{|c|}{ Control variables from the bank loan finance equation are also included in each regression. } \\
\hline Adjusted $\mathrm{R}^{2}$ & 0.29 & 0.16 & 0.18 \\
\hline Observations & 180 & 356 & 476 \\
\hline
\end{tabular}

Panel A and Panel B of this table reports the difference tests of firm characteristics between connected firms and non-connected firms. Panel $\mathrm{C}$ of this table reports the regression results using the propensity score matching method. In Panel C, T-statistics (in parentheses) are computed using robust standard error clustered by firm. *, $* *$ and $* * *$ indicate significance at the $10 \%, 5 \%$ and $1 \%$ levels, respectively.

\section{Ex-post performance}

Previous analysis concludes that lending to firms with bank connections allocates capital much more efficiently due to less information asymmetry and improved bank monitoring, while politically based lending is regarded as a form of capital misallocation (Zheng and Zhu, 2013). However, no direct evidence has been presented with respect to the consequence of individual loans. This section provides further empirical evidence regarding the ex-post performance of each bank loan to complement our previous findings. As suggested by Engelberg et al. (2012), the ideal test would be to compare the default rate (reflecting the potential risk levels) between relationship-based and non-relationship-based loans. However, the CSMAR does not provide data on whether the loan is defaulted subsequently. Thus, in the spirit of Qian and Yeung (2014), we use the probability that a firm will subsequently be flagged with ST or *ST, and its stock returns after the loan is granted, to approximately measure the ex-post performance of bank loans. In this section, we create a variable, $S T$, which is equal to 1 if a firm has been flagged with ST or *ST since the origination of the bank loan and 0 otherwise. According to the Chinese Securities Regulatory Commission (CSRC), a listed firm will be flagged with ST if this firm has shown a negative net income for two consecutive years. If an ST firm fails to recover, the flag will be changed to ${ }^{*} \mathrm{ST}$ as a warning of delisting. In relation to future stock returns, we collect stock returns 12, 24 and 36 
months after the initiation of bank loans and regress on our key variable and a set of control variables. These results are reported in Table 13.

Before proceeding, we note one important change to the sample. In the previous analysis, the unit of observation was the individual bank loans, which occasionally included multiple tranches within a bank (in the same year to different borrowers) or multiple tranches within a firm (in the same year from different banks). Following previous studies using loan-level data (Engelberg et al., 2012; Huang et al., 2012), we treated these as independent observations in our previous analysis. However, this becomes inappropriate when examining firm-level performance. Even if a firm borrows multiple loans from the same bank in the same year, this clearly constitutes only one independent observation for the firm's ex-post performance. Collapsing at the loan level reduces the sample to 274 when using the probability of entering financial distress and future stock returns as the dependent variables.

In column 1 of Table 13, the dependent variable is the probability of being flagged with ST and $*$ ST. From the estimation results, we observe that the coefficients on Bank and Political are -1.62 and 0.86 , both significant at either the $1 \%$ or $5 \%$ levels (t-values are -3.30 and 1.96, respectively). These results indicate that firms with bank connections are less likely to become financially troubled, while firms with political connections are more likely. In columns 2 to 4 of Table 13, the dependent variable is future stock returns, defined as the cumulative abnormal market-adjusted stock returns on the basis of monthly stock returns. As can be seen, the estimated coefficients on Bank are all positive and statistically significant (except for the 36-month regression), indicating that over the long-term windows returns are predictable from a firm's connections with the lending banks. However, this effect tends to disappear slightly over a three-year window. The overall results are consistent with our previous findings that loans to firms with bank connections are highly efficient and beneficial to firm shareholders. In relation to political connections, all three columns show that returns for politically connected firms are lower than those for non-politically connected firms. This is consistent with our prediction that, though political connections bring more bank loans, investors tend to discount the values of these bank loans. This is because firms are expected to return the favour to government, such as bribing government officials or paying more tax, in exchange for obtaining favourable bank loans, which may offset the benefits of political connections. In addition, the subsequent expropriation would be more severe if a loan is granted to firms with political connections.

\section{Table 13. Bank connections, political connections and ex-post performance}

$\begin{array}{lll}\text { Dependent variable } & \begin{array}{l}\text { Probability of } \\ \text { becoming ST or ST* }\end{array} & \text { Future stock returns }\end{array}$




\begin{tabular}{lllll}
\hline & & $12-$ months & 24-months & $36-$ months \\
\cline { 2 - 5 } Bank & $-1.62 * * *(-3.30)$ & $0.07 * *(3.07)$ & $0.17 * *(3.97)$ & $0.09(0.88)$ \\
Political & $0.86 * *(1.96)$ & $-0.08 * * *(-3.52)$ & $-0.08 * * *(-2.04)$ & $-0.10 * * *(-1.97)$ \\
Control variables from & equation $(1)$ are also included in these regressions & \\
Observations & 274 & 274 & 274 & 274 \\
Adjusted $\mathrm{R}^{2}$ & 0.33 & 0.17 & 0.16 & 0.14 \\
\hline
\end{tabular}

This table relates firms' probability of entering financial distress and future stock returns of the borrower to bank connections and political connections. The control variables from our equation (1) are also included in all regressions.

The T-statistics (Z-statistics) (in parentheses) are computed using robust standard error clustered by firm. *,** and $* * *$ indicate the significance levels at $10 \%, 5 \%$ and $1 \%$, respectively.

\section{Conclusion}

The objective of this study is to examine the financial implications of firms' connections with both banks and governments for banks' lending decisions. Using bank loan level data between 2003 and 2010, we find that the amount of bank loans is more closely related to profitability for firms with bank connections, while bank loans granted to firms with political connections are less influenced by firm profitability. We also find that the impact of bank connections on bank lending decisions becomes more pronounced in less supported industries and less developed regions. Further analysis also shows that while bank-connected executives can use their financial skills to access more bank loans, their effect on mitigating information asymmetry is significantly larger. This evidence supports our argument that bank connections can alleviate severe information asymmetry and interest conflicts between firms and banks and reduce bank monitoring costs, which may result from ideological discrimination and market failure.

With regard to market reactions to bank-loan announcements, we find that both firm and bank investors are optimistic about announcements of bank loans granted to firms with bank connections, while they discount the value of bank loans granted to firms with political connections. Furthermore, borrowers with bank connections are much less likely to become financially distressed, and they exhibit higher future stock returns, once their bank loans are initiated, while borrowers with political connections are significantly more likely to become financially distressed, and they exhibit lower future stock returns. Additional analysis further suggests that the effect of bank connections becomes more profound when firms borrow from banks where firm executives used to work.

Overall, we argue that in an emerging market, where the financial and legal system is underdeveloped and legal protection for creditors and investors is weak, bank connections can be a substitute for legal protection, and effectively alleviate information asymmetry and improve capital allocation efficiency. However, political connections are exploited through exerting political pressure, which may not reduce the credit risk and could lead to capital 
misallocation. Our evidence helps to explain the coexistence of a weak institutional framework and vibrant private-sector growth in China.

\section{Appendix 1. Identification of supported industries}

Panel A: The tenth Five-Year Plan

The following industries are included in the tenth Five-Year Plan as supported industries: A01 Agriculture, A03 Forestry, A05 Livestock farming, A07 Fishery, A09 Agriculture, Forestry, Livestock farming, Fishery, B Mining, C43 Chemical material and products manufacturing, C47 Chemical fibre production, C48 Rubber production, C49 Plastic production, C51 Electric-parts manufacturing, C67 Ferrous-metal foundries and presses, C69 Metal production, C73 Special-equipment manufacturing, C75 Transportation-equipment manufacturing, C76 Electric-equipment manufacturing, C81 Medicine manufacturing, C85 Biological products, D01 Electricity, steam and hot-water production and supply, D03 Gas production and supply, E01 Civilengineering building, F01 Railway transportation, F03 Highway transportation, F05 Pipeline transportation, F07 Waterway transportation, F09 Air transportation, G81 Telecommunication and equipment manufacturing, G85 Telecommunication service, G87 Computer application and service, J01 Real estate management, H11 Retail.

Panel B: The eleventh Five Year Plan

The following industries are included in the eleventh Five-Year Plan as supported industries: A01 Agriculture, A03 Forestry, A05 Livestock farming, A07 Fishery, A09 Agriculture, Forestry, Livestock farming, Fishery, C01 Food processing, C43 Chemical material and products manufacturing, C51 Electric-parts manufacturing, C67 Ferrous-metal foundries and presses, C73 Special-equipment manufacturing, C75 Transportationequipment manufacturing, C76 Electric-equipment manufacturing, C81 Medicine manufacturing, C85 Biological products, D01 Electric power, steam and hot-water production and supply, D03 Gas production and supply, F01 Railway transportation, F03 Highway transportation, F05 Pipeline transportation, F07 Waterway transportation, F09 Air transportation, F11 Transportation auxiliary, G81 Telecommunication and equipment manufacturing, G85 Telecommunication service, G87 Computer application and service, J01 Real estate management, K01 Public service, K34 Tourism. 


\section{References}

Allen, F., Qian, J., Qian, M., 2005. Law, finance, and economic growth in China. Journal of Financial Economics 77, 57-116.

Behr, P., Entzian, A., Guttler, A., 2011. How do lending relationships affect access to credit and loan conditions in microlending? Journal of Banking and Finance 35(8), 2169-2178.

Bharath, S.T., Dahiya, S., Saunders, A., Srinivasan, A., 2011. Lending relationships and loan contract terms. Review of Financial Studies 24(4), 1141-1203.

Boot, A., Thakor, A., 1994. Moral hazard and secured lending in an infinitely repeated credit market game. International Economic Review 35(4), 899-920.

Boot, A., 2000. Relationship banking: What do we know? Journal of Financial Intermediation 9, 7-25.

Brennan, M., Subrahmanyam, A., 1995. Investment analysis and price formation in securities markets. Journal of Financial Economics 38, 361-381.

Chen, J.P., Li, Z., Su, X., Sun, Z., 2011a. Rent seeking incentives, corporate political connections and the control structure of private firms: Chinese evidence. Journal of Corporate Finance 17(2), 229-243.

Chen, S., Sun, Z., Tang, S., Wu, D., 2011b. Government intervention and investment efficiency: Evidence from China. Journal of Corporate Finance 17, 259-271.

Chen, Y., Liu, M., Su, L., 2013. Greasing the wheels of bank lending: Evidence from private firms in China. Journal of Banking and Finance, forthcoming.

Claessens, S., Feijen, E., Laeven, L., 2008. Political connections and preferential access to finance: The role of campaign contributions. Journal of Financial Economics 88, 554-580.

Cull, R., Xu, L., 2003. Who gets credit? The behaviour of bureaucrats and state banks in allocating credit to Chinese state-owned enterprises. Journal of Development Economics 71, 533-559.

Cull, R., Xu, L., 2005. Institutions, ownership, and finance: the determinants of profit reinvestment among Chinese firms. Journal of Financial Economics 77, 117-146.

Custodio, C., Metzger, D., 2014. Financial expert CEOs: CEO's work experience and firm's financial policy. Journal of Financial Economics 114, 125-154.

Engelberg, J., Gao, P., Parsons, C. A., 2012. Friends with money. Journal of Financial Economics 103, 169-188.

Faccio, M., Masulis, R.W., McConnell, J.J., 2006. Political connections and corporate bailouts. Journal of Finance 61 (6), 2597-2635. 
Faccio, M., 2010. Differences between politically connected and nonconnected firms: A cross-country analysis. Financial Management 39(3), 905-928.

Fan, J. P. H., Wong, T. J., Zhang, T., 2007. Politically connected CEOs, corporate governance and post-IPO performance of China's newly partially privatized firms. Journal of Financial Economics 84, 330-357.

Fan, G., Wang, X., Zhu, H., 2011. The marketization index of China: The process of regional marketization report 2011. Beijing: Economic Science Press.

Firth, M., Lin, C., Liu, P., Wong, S. M. L., 2009. Inside the black box: Bank credit allocation in China's private sector. Journal of Banking and Finance 33, 1144-1155.

Haselmann, R., Schoenherr, D. and Vig, V., 2013. Lending in social networks, working paper.

Heckman, J., 1979. Sample section bias as a specification error. Econometrica 47(1), 153161.

Houston, J., Jiang, L., Lin, C., Ma, Y., 2014. Political connections and the cost of bank loans. Journal of Accounting Research 52(1), 193-243.

Huang, W., Schwienbacher, A., Zhao, S., 2012. When bank loans are bad news: Evidence from market reactions to loan announcements under the risk of expropriation. Journal of International Financial Markets, Institutions and Money 22(2), 233-252.

Huang, Q., Jiang, F., Lie, E., Yang, K., 2014. The role of investment banker director in M\&A. Journal of Financial Economics 112, 269-286.

Kano, M., Uchida, H., Udell, G., Watanabe, W., 2011. Information verifiability, bank organization, bank competition and bank-firm relationships. Journal of Banking and Finance $35(4), 935-954$.

Leland, H. E., Pyle, D. H., 1977. Informational asymmetries, financial structure and financial intermediation. Journal of Finance 32(2), 371-387.

Li, H. B., Meng, L., Wang, Q., Zhou, L., 2008. Political connections, financing and firm performance: Evidence from Chinese private firms. Journal of Development Economics 87, 283-299.

Li, K., Yue, H., Zhao, L., 2009. Ownership, institutions, and capital structure: Evidence from China. Journal of Comparative Economics 37 (3), 471-490.

Liu, Q., Pan, X., Tian, G., 2016. To what extent did the economic stimulus package influence bank lending and firm investment decisions? Evidence from China, Journal of Banking and Finance, forthcoming. 
Qi, Y., Roth, L., Wald, J., 2010. Political rights and the cost of debt. Journal of Financial Economics 95, 202-226.

Qian, M., Yeung, B., 2014. Bank financing and corporate governance. Journal of Corporate Finance. Forthcoming.

Rajan, R., 1992. Insider and outsiders: The choice between informed and arm-length debt. Journal of Finance 47(4), 1367-1400.

Sharpe, S. A., 1990. Asymmetric information, bank lending and implicit contracts: A stylized model of customer relationships. Journal of Finance 45(4), 1069-1087.

Shleifer, A., Vishny, R., 1997. A survey of corporate governance. Journal of Finance 52(2), 737-783.

Sufi, A., 2007. Information asymmetry and financing arrangements: Evidence from syndicated loans. Journal of Finance 62(2), 629-668.

Villalonga, B., Amit, R., 2006. How do family ownership, control and management affect firm value? Journal of Financial Economics 80, 385-417.

Wei, S. J., Wang, T., 1997. The Siamese twins: Do state owned banks favour state owned enterprises in China? China Economic Review 8(1), 19-29.

Wu, W., Wu, C., Rui, M., 2012. Ownership and the value of political connections: Evidence from China. European Financial Management 18(4), 695-729.

Yang, J. Y., and Qian, H., 2008. Survey evidence on commercial bank mortgage loans. Journal of Financial Research 333, 79-87 (in Chinese).

Yeung, G., 2009. How banks in China make lending decisions. Journal of Contemporary China 18(59), 285-302.

Zheng, Y., Zhu, Y., 2013. Bank lending incentives and firm investment decisions in China. Journal of Multinational Financial Management 23, 146-165. 